\title{
Research on Implementation and Evaluation of Highway Green Construction
}

\author{
Ke Yao ${ }^{1 *}$, Zhichao Sun ${ }^{1}$, Mengyue $\mathrm{Li}^{1}$, Qingqing Fan ${ }^{1}$, Guojun $\mathrm{Hao}^{1}$ \\ ${ }^{1}$ Guangdong Provincial Transport Planning and Research Center, Guangzhou, 510101, China
}

\begin{abstract}
This article analyzes how to implement green construction in highway construction around six aspects of highway green construction management, construction material saving, water saving, energy saving, land saving and environmental protection. According to the control and non-control work, this article studies how to evaluate the implementation effect of highway green construction from the aspects of sub-elements, sub-batches, sub-project categories and sub-stages. The proposed implementation plan, evaluation method and evaluation organization of highway green construction can provide technical reference for the implementation of highway green construction.
\end{abstract}

\section{Introduction}

The construction and development of modern transportation must be integrated with the sustainable ecological environment. In the course of construction, highway projects will occupy land, consume resources, and affect and destroy the environment to a certain extent. How to achieve the minimum resource consumption, the minimum energy consumption and the minimum negative impact on the environment in highway construction, and how to achieve the green goal of resource conservation, environmental friendliness, energy conservation and high efficiency during the construction process are the new requirements of modern engineering construction. The implementation of green construction will be an effective means to meet the new requirements of highway construction. This article will analyze how to implement green construction and how to carry out green construction evaluation in highway construction.

\section{Implementation analysis of highway green construction}

In the course of the construction of highway project, the green construction should be carried out from the aspects of construction environment protection, material, energy and water resources saving and recycling, and land resources saving and protection.Through the implementation of material saving, water saving, energy saving, land saving and environmental protection and other technical measures, strengthen system construction and site management, make the highway construction meet the requirements of green ecology.

\subsection{Green construction management:}

- Establish green construction management system and implement management by objectives. Promoting green construction of highway construction requires the establishment of a sound green construction management system and management system. In the management system, the organizational structure should be determined, the management responsibilities of relevant personnel should be clarified, and the supervision responsibilities should be implemented to people. Management systems and emergency plans should be established for material saving, water saving, energy saving, land saving, environmental protection and occupational health and safety of construction personnel. The implementation of management by objectives requires clear environmental protection goals, and the conservation, recycling and protection objectives of materials, water, energy and land for the project construction.

- Perfect drawing design and construction plan. In the review stage of the design drawings, the impact of the project construction on the surrounding environment should be reviewed, especially the setting of structures, protection forms and drainage design, to further improve the drawings design. According to the requirements of green construction, special green construction chapters shall be added to the construction organization design and construction plan, which shall cover the specific engineering measures and technical requirements of green construction management

\footnotetext{
"Corresponding author's e-mail: 45843338@qq.com
} 
and material saving, water saving, energy saving, land saving and environmental protection

- Implement green construction management. The main tasks are as follows: incorporating the relevant content of green construction into the engineering and technical submission of design and construction; setting up a green construction expert committee to conduct full-process technical consultation on green construction schemes and implementation; regularly carrying out green construction self-inspection and evaluation, and conducting file management of green construction process management data; according to the requirements of green construction, carry out regular green construction inspection, and formulate continuous improvement measures to implement.

\subsection{Highway construction environment protection:}

During highway construction, there are many sources of environmental pollution and damage, including: dust pollution, water pollution, engineering waste pollution, and noise source pollution. Firstly, environmental protection targets for different types of pollution should be established, such as control targets for dust, water pollution and noise, and targets for the production and recycling rate of project garbage. Then, targeted protection and protection measures should be taken for various types of pollution and the proposed targets.

- Construction dust control. Sprinkling, covering and other dust suppression measures shall be taken for construction roads, exposed soil and centralized earthwork; to take sealing or covering measures for vehicles prone to dust; combined with the sewage recycling facilities of the construction site, set up a car wash tank at the site entrance and exit to clean the engineering vehicles; closed storage of construction materials that are easy to fly and fine particles; take shelter and dust removal measures for construction work that is easy to produce dust; dust blasting technology and dust removal measures are adopted in blasting operation of tunnel and rock slope; establish the system of cleaning dust by drying water, equip with relevant equipment and use scientifically.

- Sewage discharge control. Drainage ditches are set up around roads and material storage sites at the construction site to collect rainwater for centralized drainage. Sewage sedimentation tanks are set up in the steel reinforcement processing plant, concrete mixing station, bridge beam and slab prefabrication plant, etc., so that construction sewage can be discharged after precipitation treatment. In the construction site to achieve construction sewage and rainwater diversion discharge. Site kitchen set grease trap, construction site toilet set septic tank, and regular professional cleaning.

- Engineering waste disposal. Construction waste such as construction muck and silt shall be discharged in compliance with the premise of obtaining the discharge license. The engineering waste shall be collected by classification and stacked in a concentrated manner. Materials such as crushed stones and earthwork should be used as backfill material for foundation and subgrade, and the recycling rate of engineering waste should be above $50 \%$.

- Construction noise control. In the selection of construction equipment, low-noise equipment and technology should be used for construction. Noise monitoring points should be set up on the construction site for dynamic monitoring. During the construction process, the construction machinery that generates noise should be far away from the office area, living area and surrounding residential areas, and effective noise reduction and sound insulation measures shall be adopted. The emission of construction noise shall comply with the provisions on prohibited construction time and noise intensity.

\subsection{Highway construction material saving and utilization:}

In the construction organization design and construction plan, it is necessary to make clear the material procurement and turnover plan, material saving and utilization plan, make clear the material loss rate and recycling utilization rate, and ensure the reasonable use of materials.

- Material selection. Green and environmentally friendly construction materials should be selected in priority, and local construction materials should be mainly used to reduce the transportation distance of materials. Detachable and recyclable materials shall be used for temporary facilities and temporary protective facilities. Reduce material usage by using high strength materials. Adopt standard, assembly and standardized construction materials and processes to improve the yield of materials and construction efficiency.

- Material saving. Highway structures and small components should be standardized and assembled, and mechanical and electrical installations should be integrated pipeline optimization design to reduce material consumption and wastage. During the construction process, especially in the construction links such as reinforcement processing, concrete mixing, and bridge beam and slab prefabrication, new technologies should be fully applied, and information technology should be used to improve the 
efficiency of material use and reduce material consumption.

- Material recycling. During the construction process, the surplus materials of construction materials and equipment should be used reasonably, the packaging materials of construction materials and equipment should all be recycled, the road topsoil should be collected for afforestation and planting, and the existing buildings and municipal facilities should be fully utilized in the construction of construction facilities. For the pavement overhaul and road reconstruction project, the original pavement materials and guardrail facilities should be used scientifically and rationally.

\subsection{Highway construction water saving and utilization:}

The water saving goal of the entire construction process should be clarified, and water saving measures and water resource utilization plans for each construction link should be formulated, which should be strictly implemented during the construction process.

- Construction water saving. The construction water saving management system should be established, and the water supply network on the construction site should be designed rationally, and water saving construction technology and measures should be adopted during the construction process. All domestic water used at the construction site shall be equipped with water-saving appliances, and the domestic water and production water shall be measured and assessed respectively. Strengthen the daily management and maintenance of water equipment to prevent leakage of pipe network and water appliances. Carry out the propaganda of water saving in construction and improve the consciousness of water saving of construction personnel.

- Water resource utilization. Natural water such as construction water and rainwater should be collected and used. Natural water should be used as far as possible and tap water should be reduced. The system of water resources reuse collection and treatment shall be established, and the equipment of sewage purification and reuse shall be equipped to realize the recycling of production and domestic sewage after treatment. During the construction process, concrete mixing and health maintenance, road spraying, greening irrigation, washing construction vehicles and equipment and other construction links should use natural water or recycling water instead of tap water.

\subsection{Highway construction energy saving and utilization:}

It is necessary to make clear the energy-saving target of highway project construction, and strictly control the allocation rate of electricity, fuel, gas and energy-saving equipment in office, living and construction area by setting the target.

- Energy saving of electric facilities. Establish a temporary electricity management system to measure and assess electricity consumption in office, living and construction areas. Energysaving lighting lamps should be adopted and automatic lighting control such as voice control and light control should be adopted. During the construction process, temporary power facilities shall be reasonably equipped, energy-saving products shall be adopted and automatic control devices shall be equipped. The lighting design of the construction site should meet the requirements of relevant codes, and try to use renewable energy such as solar energy and wind energy.

- Energy saving of mechanical equipment. Establish construction equipment management system, establish equipment technical files, implement equipment regular maintenance. During the construction process, the construction equipment with high energy efficiency should be selected, the construction sequence should be reasonably arranged, and the resource sharing of construction equipment should be implemented to reduce the number of equipment in the operation area. After the completion of the construction should be turned off in time to reduce energy consumption of equipment.

- Energy saving of temporary facilities. Temporarily arrange temporary facilities in office, living and construction areas, and use natural light as far as possible to ensure good ventilation and reduce electricity consumption. Temporary facilities should use composite wall and roof panels that meet thermal performance standards. Sun protection measures such as curtains and sunshades should be used to reduce temperature control energy consumption.

- Energy saving in site construction. During the construction process, the construction process and progress should be reasonably arranged, the construction technology and process with low energy consumption should be adopted, and the transportation distance of building materials should be shortened by selecting local materials, so as to reduce the time of night operation and the energy consumption of lighting. Measures should be taken to reduce secondary material handling in the field. 


\subsection{Highway construction land saving and protection:}

Before the organization of construction, the construction site should be combined with the situation of the construction site, the area of the construction site and the land protection during the construction process should be subject to objective control, and strict control management should be implemented.

- Land saving.Reducing land occupation as the first principle of construction site layout, compact layout of the construction site and implementation of dynamic management. Reasonable design of the site road, the maximum implementation of the combination of permanent and temporary, make the temporary road layout of construction combined with the original road and permanent road, and combine the temporary construction facilities with the original building and permanent building. The temporary construction facilities that need to be built should adopt reusable assembled structures.

- Land protection. Before organizing the construction, the construction unit should fully understand the protection requirements of the construction site and adjacent areas of cultural landscape and the distribution of infrastructure pipelines, and formulate detailed construction protection measures. During the construction process, the removal and abandonment of soil shall be carried out at the specified sites, and effective measures shall be taken to prevent soil erosion and protect the original vegetation within the construction site. Damaged vegetation shall be restored as soon as possible after construction.

\section{Research on evaluation of highway green construction}

\subsection{Evaluation method:}

The implementation of green construction in highway construction projects mainly focuses on the six elements of green construction management, material saving, water saving, energy saving, land saving and environmental protection. To evaluate the implementation of green construction of highway construction project, we should first combine the construction characteristics and requirements of the project and divide the specific work of the above six elements into control work and non-control work. The control work is defined as the control work. If it is not implemented during the construction process, the green construction of the project will be rejected. The noncontrol work is graded, and the scoring criteria for each work are shown in Table 1. The total score of noncontrol work of each factor is calculated by a percentage system, and the formula is as follows:

$$
\mathrm{S}_{\mathrm{i}}=\sum_{\mathrm{j}=1}^{\mathrm{n}} \mathrm{A}_{\mathrm{j}} / 5 n \times 100
$$

Where $S_{i}$ is the total score of non-control work of each element, $i$ is 6 elements, $j$ is non-control work of each element, $n$ is the total number of non-control work of each element, $A_{j}$ is the score of non-control work.

Table 1. The scoring criteria of non-control work

\begin{tabular}{|c|c|}
\hline Scoring requirements & Score \\
\hline $\begin{array}{c}\text { Measures are in place to fully meet the requirements of the evaluation } \\
\text { indicators }\end{array}$ & 5 \\
\hline $\begin{array}{c}\text { Measures are basically in place to better meet the requirements of the } \\
\text { evaluation indicators }\end{array}$ & $3-4$ \\
\hline Measures partly meet the requirements of the evaluation indicators & $1-2$ \\
\hline $\begin{array}{c}\text { Measures are not in place, do not meet the requirements of the evaluation } \\
\text { indicators }\end{array}$ & 0 \\
\hline
\end{tabular}

The highway construction could be divide into four sub-project including subgrade engineering, bridge and tunnel engineering, pavement engineering and traffic safety engineering. Batch evaluation and phase evaluation could be adopted to estimate the green construction of each sub-project. The weight coefficients of the six elements in each sub-project are shown in table 2. The calculation formula of batch evaluation is as follows: The total score of non-control work of each factor is calculated by a percentage system, and the formula is as follows:

$$
\mathrm{E}=\sum_{\mathrm{i}=1}^{6}\left(\mathrm{~S}_{\mathrm{i}} \times \mathrm{k}\right)
$$

Where $\mathrm{E}$ is the score of each sub-project's batch evaluation, $\mathrm{Si}, \mathrm{i}$ are the same as above, $\mathrm{k}$ is the weight coefficient which are shown in table 2.

The calculation formula of phase evaluation is as follows:

$$
\mathrm{G}=\sum_{\mathrm{x}=1}^{\mathrm{m}} \mathrm{E}_{\mathrm{x}} / m
$$

Where $G$ is the score of each sub-project's phase evaluation, Ex is the score of each sub project's batch evaluation, and $\mathrm{m}$ is the number of batch evaluation. 
Table 2. Batch evaluation factor weight coefficient

\begin{tabular}{|c|c|c|c|c|}
\hline & $\begin{array}{c}\text { Subgrade } \\
\text { engineering }\end{array}$ & $\begin{array}{c}\text { Bridge and tunnel } \\
\text { engineering }\end{array}$ & $\begin{array}{c}\text { Pavement } \\
\text { engineering }\end{array}$ & $\begin{array}{c}\text { Traffic safety } \\
\text { engineering }\end{array}$ \\
\hline $\begin{array}{c}\text { Green } \\
\text { construction } \\
\text { management }\end{array}$ & \multicolumn{3}{|c|}{0.10} \\
\hline $\begin{array}{c}\text { Environmental } \\
\text { protection }\end{array}$ & \multicolumn{5}{|c|}{0.35} \\
\hline $\begin{array}{c}\text { Material saving } \\
\text { Water saving }\end{array}$ & 0.10 & 0.20 & 0.10 & 0.20 \\
\hline Energy saving & 0.20 & 0.15 & 0.10 & 0.10 \\
\hline Land saving & 0.15 & 0.10 & 0.20 & 0.15 \\
\hline
\end{tabular}

The green construction evaluation of highway construction projects is calculated according to the following formula, and the weight coefficients of each sub-project in the green construction evaluation are shown in Table 3.

$$
\mathrm{W}=\sum_{\mathrm{t}=1}^{4}\left(\mathrm{G}_{\mathrm{t}} \times \mathrm{p}\right)
$$

Where $W$ is the green construction evaluation score of highway construction project, $t$ is the evaluation score of four sub-projects, $G_{t}$ is the evaluation score of each sub-project stage, and $p$ is the weight coefficient of subproject, as shown in table 3.

Table 3. Weight coefficient of sub-project

\begin{tabular}{|c|c|}
\hline Sub-project & Weight coefficient \\
\hline Subgrade engineering & 0.3 \\
\hline $\begin{array}{c}\text { Bridge and tunnel } \\
\text { engineering }\end{array}$ & 0.4 \\
\hline Pavement engineering & 0.2 \\
\hline Traffic safety engineering & 0.1 \\
\hline
\end{tabular}

The green construction grade of highway construction project is determined according to the following conditions. The green construction evaluation score $\mathrm{W}<60$ is unqualified, $60 \leq \mathrm{W}<85$ is qualified, $\mathrm{W} \geq 85$ is excellent.

\subsection{Evaluation implementation}

Highway construction projects implement green construction. During the construction process, batch evaluation of each sub-project should be carried out every 2 months, and batch evaluation of each sub-project should not be less than 2 times. Batch evaluation shall be organized by the construction unit, the project construction unit and the supervision unit. The stage evaluation of the green construction of each sub-project shall be conducted after the completion of the sub-project, and shall be organized by the supervision unit, the project construction unit and the construction unit. The green construction evaluation of the project shall be conducted after the completion of the project, and shall be organized by the construction unit, the project supervision unit and the construction unit. The evaluation results of the 3 types of evaluation shall be signed by the construction, supervision and construction units. After each batch evaluation, the construction unit shall, together with the construction unit and the supervision unit, formulate improvement measures according to the evaluation results and the green construction of the project, and implement them in the follow-up construction.

In order to ensure the green construction quality of the project, the construction unit may entrust the technical consulting institution to formulate the green construction plan of the project, carry out regular green construction inspection and provide technical services for the 3 types of evaluation.

\section{Conclusions}

Green construction refers to the construction activities to save resources and reduce the negative impact on the environment to the maximum extent through scientific management and technical application under the basic requirements of quality and safety. The premise of implementing green construction in highway construction is to establish a management system and implement green construction management. At the same time, it is necessary to formulate implementation plans for material saving, water saving, energy saving, land saving and environmental protection, define control objectives, apply technical means and implement construction requirements. In response to the implementation of highway green construction, scientific evaluation should be conducted according to factors, batches, project categories and stages, so as to determine the implementation effect of green construction. The implementation scheme and evaluation method of green construction proposed in this paper will provide reference for highway construction projects to carry out green construction.

\section{References}

1. Ouyang, B., Li, Z.K. (2014) Strategic thinking of green highway development. Traffic construction and management, (22): 128-132+136. 
2. Xiong,Y., Xie,W.X. (2015)The modeling research on evaluation of green construction of the highgrade highway. Transportation science and technology, (01):73-76.

3. Tang,B.H., Wei,Q. (2007)Idea and requirement in the green construction of road building project. Modern transportation technology, 4(01):85-87.

4. Li,X.J. (2017)Green construction evaluation of mountain highway projects. Journal of engineering management, 31(06):83-88.

5. Wei,Y.F. (2014) Construction technology of highway bridge under background of green construction. Transportation standardization, 42(04):68-70.

6. Tang,Y. (2018) Green construction technology and management of highway bridge. Northern transportation, (08):92-94.

7. Zhao,H., Li,X.B., Dong,H.H., Ren,T.C. (2019) Research on ecological environmental protection in construction period of highway project. Energy Conservation \& Environmental Protection in Transportation, 15(02):73-76.

8. Sun,Q.B., Zhen,X.Y. (2000) Damages to ecological environment caused by expressway construction and its and recovery. Journal of Kunming University of Science and Technology, 25(02):68-71.

9. Zhang,Z.J., Zhang,L.J., Zhang,Y. (2010) Effect of expressways on environment pollution and the protection strategies. Journal of Southwest China Normal University (Natural Science Edition), 35(02):127-131.

10. Luo,T.C. (2013) Study on air environment impact during highway construction. Highway, (02):198201. 